This draft: April 27, 2007

\title{
Liberalizing Trade under Structural Constraints in Developing Countries. A General Equilibrium Analysis of Tanzania
}

\author{
By \\ Piero Conforti and Alexander Sarris ${ }^{1}$
}

\begin{abstract}
$\underline{\text { Abstract }}$
The paper uses a computable general equilibrium (CGE) model of Tanzania, that includes considerable factor disaggregation and household detail, to explore the impact of trade liberalization on growth and poverty alleviation. The focus is on the impact of trade liberalization policies under different structural constraints, such as large marketing margins between producers and the market. The first major conclusion that obtains from the empirical results is that the nature of the macroeconomic and sectoral market adjustment makes a large difference on the results of the liberalization scenario. In particular, the functioning of the labor market appears to make for significant differences in the outcome of tariff cuts. A closure that seems empirically relevant to Tanzania is adopted and several policy scenarios are run. The policy that seems to be the most appropriate for poverty reduction is the one where marketing margins decrease. By contrast, the scenario that assumes significant further unilateral trade liberalization does not seem to produce significant GDP changes, nor does it produce significant changes in household welfare, despite the large degree of liberalization assumed. Hence trade liberalization appears not to be a panacea for growth and poverty alleviation in Tanzania without supply side interventions.
\end{abstract}

\footnotetext{
${ }^{1}$ Paper presented at the Tenth Anniversary Conference of the Global Trade Analysis Project on "Assessing the Foundations of Global Economic Analysis", Organized Session on "The Implications of Trade Liberalization for Developing Countries under Different Structural Assumptions”, West Lafayette, IN, Usa, 7-9 June 2007.

Piero Conforti is an Economist and Alexander Sarris is Director at the Trade and Markets Division of the Food and Agriculture Organization (FAO) of the United Nations. The authors would like to acknowledge the help from Peter Wobst who kindly provided helpful comments as well as data and parameters relevant to the model implemented here. No senior authorship is assigned.
} 


\section{Introduction}

The purpose of this paper is to explore trade liberalization in the context of structural features that are endemic in low income agriculture dependent economies. In most developing countries, major policy changes like trade liberalization would necessarily take place against a background characterized by significant structural constraints, which affect the functioning of markets and their degree of completeness and competitiveness. Common characteristics of such contexts are backward technologies and poor infrastructural endowments, resulting in large market weaknesses. This is especially the case of agricultural production, and of the more traditional parts of the food chain. Where subsistence farming is widespread, a significant portion of households' consumption flows directly from production into selfconsumption, bypassing the specialized processing and distribution systems. Food processing and marketing usually show high transaction costs arising from poor infrastructures, such as inadequate physical transport facilities, and by institutional and physical gaps in the organization of activities.

Any policy change, if taking place in a context of such structural features, is likely to bring about considerable economy-wide effects, which are complex in nature, and spread across institutions. The structural features that will be of major concern in this study are large marketing margins for agricultural products and the functioning of labor markets. The extent to which the labour market is characterized by rigidities - such as those limiting changes in wages and/or in employment - can shape the social implications of a policy change, in terms of welfare of the different social groups in the country. There are few doubts that the more policy analysis allows for such potential effects to be taken into account and analyzed, the more policy design can be effective. Trade liberalization is a particularly sensitive policy issue, and it has been shown analytically that the potential impacts are deeply affected by assumptions concerning the structure of the labour market (Ackerman, 2005; Taylor and von Arnim, 2006).

Most analyses of global and national trade liberalization, including those pertaining to agriculture, have also not dealt with questions involving the existence or reductions in margins between producers and consumers, caused by inadequate infrastructure, such as transport costs, as well as transactions costs due to various market regulations, etc. Furthermore, such analyses almost always assume perfect price transmission between world prices and domestic market prices. Such analyses, however, miss one of the most important aspects of underdevelopment and rural poverty especially in Africa. For instance, a recent analysis in Madagascar suggests that the existence of high transactions costs, such as high transport margins between remote and central regions are associated with lower input use, reduced yields and (consequently) higher incidence of poverty (Stifel, Minten and Dorosh, 2003). Minot comes to similar conclusions for Tanzania (2005). Similarly, studies by Delgado, Minot and Tiongco (2003) and Kilima (2006) independently find that international and local markets in Tanzania are not well connected, rendering many staple food products essentially non-tradable. This suggests that the existence of large marketing margins can have strong effects on any trade policy changes.

There have been some recent studies that attempted to include marketing margins in analyses of economy-wide impacts of trade liberalization and other policies. Arndt et. al. (2000) found in their analysis of Mozambique that not only the macroeconomic effects of reducing marketing margins are significant, but also that there are synergies between simultaneously increasing agricultural productivity and reducing marketing margins. They did not, however, analyze impacts of trade policies. Wobst (2003) explicitly included marketing costs in his analysis of the impact of trade liberalization in five Southern Africa Countries, using 
computable general equilibrium (CGE) models. He found that reductions in marketing costs improve considerably the export performance, did not include in his paper any poverty related impacts.

This paper discusses trade liberalization with reference to one specific Eastern African country, Tanzania, and examines the effects of this policy in connection with changes in the marketing margins. The analysis is based on a 2001 Social Accounting Matrix (SAM) for Tanzania, built from the data provided by IFPRI (Thurlow and Wobst, 2003), which includes considerable factor, household, and sectoral detail. The simulations presented are run with a computable general equilibrium (CGE) model, which is run under a wide set of different closure rules, implying different assumptions concerning the way in which adjustment takes place in the economy.

The paper proceeds in the next section to discuss the Tanzanian context, and the structural features of the economy. Section 3 discusses the features of the CGE model of Tanzania. Section 4 discusses issues of how markets work (the closure rules), and how they are modeled in the CGE, focusing particularly on the representation of the labor market. Section 5 reports the results of the simulations, while the last section concludes.

\section{The Tanzanian context}

Tanzania is among the world's poorest countries, with a per-capita income of about US $\$ 280$. During most of its post-independence history, the country pursued socialist policies which resulted in extended periods of below-potential economic performance. From the mid-1908s, Tanzania embarked on economic reforms which were not sustained, and after an initial period of economic growth in the late eighties, the early 1990s were again characterized by macroeconomic disequilibria and poor economic growth.

By the 1990s the country resumed its reform course with a clear and sustained commitment to macro-economic stability through sound fiscal and monetary policies as a foundation for economic growth. Macro-economic stabilization was accompanied by wide ranging structural reforms, including privatization of state owned enterprises, liberalization of the agricultural sector, efforts to improve the business environment, and strengthening of public expenditure management. These reforms have resulted in sustained growth, which in the last few years was above five percent annually.

From a macroeconomic perspective, agriculture plays a dominant role, accounting for nearly $45 \%$ of GDP, and employing around $70 \%$ of labour force. Agriculture accounts for three quarters of merchandise exports and represents a source of livelihood to about $80 \%$ of the population. Agriculture is the main source of income for the poor, especially in rural areas, and households that rely heavily on such income tend to be extremely poor. Poor households are more likely to grow and sell crops than non-poor ones, and the majority of their production is not sold, but rather consumed directly.

Smallholder farmers characterize Tanzanian agriculture. The average farm size varies mostly between less than 1 and 3 hectares, and the vast majority of the crop area is cultivated by hand. The main food crops are maize, rice, wheat, sorghum/millet, cassava and beans, occupying nearly $85 \%$ of the arable land. Bananas are grown mainly in the Kagera and Kilimanjaro areas, and like cassava, have a low value-to-bulk ratio, and are generally retained for home consumption.

Export crops represent $12 \%$ of the value of total crop production. Starting from the early 1990s, State participation and control over marketing and input supply has been gradually reduced. When the subsidy on fertilizers was lifted, the immediate consequence was an increase in the proportion of the market prices received by producers, which in turn resulted 
in a stabilization of production, which took place in spite of falling world prices. Since agriculture is still to a large extent dependent upon unpaid family labour - particularly of women and children who account for at least 70 percent of total agricultural labour - the reduced incentives in the traditional export crops has affected also the food crop sector. As a result, today male workers are attracted by commercial food crops, such as maize, or beans, which were traditio nally controlled by women.

In general, five factors contribute to low productivity in agriculture in Tanzania: (i) low input use; (ii) low prices compared to production costs; (iii) unfavourable weather conditions; (iv) pests and diseases; $(v)$ poor knowledge of agronomic practices; (vi) low levels of capital, especially for small scale farmers. Moreover, agriculture is mostly rain fed, and both crops and livestock are adversely affected by periodical droughts.

Nevertheless, earlier studies (Government of the URT, World Bank and IFPRI, 2000) indicated that the country enjoys comparative advantage in all its major export crops and in several of the main food crops, despite the low levels of technology. These studies also highlighted the presence of significant linkages between the production of exportable agricultural goods and rural incomes and growth; agricultural development and increased productivity are therefore crucial for both economic growth and poverty alleviation.

Poverty levels are high in Tanzania. During the past decade, a reduction has occurred mainly in urban poverty, while rural areas have seen relatively little change. The aggregate poverty level in 2000/01 was 35.7 percent compared to 38.6 percent in 1991/2, but in rural areas 39.9 percent of households were below the basic needs line ${ }^{2}$, accounting for about 81 percent of all the poor population. In 1991/2, the poverty level of this same type of households - depending on agriculture for their livelihood - was 42.3 percent.

Within agriculture, poverty levels are highest among households depending on livestock (59.1 percent), while is 40.6 percent for those depending on food crops, 38.6 percent for those depending on cash crops ${ }^{3}$, and 33.3 percent for those depending on livestock products. Such figures are not surprising, given that the agricultural sector only expanded at 3.5 percent per year over the past decade, corresponding to less than 1 percent per capita terms. This pattern suggests that agricultural development and better farm-gate prices can potentially result in significant poverty reductions.

A recent study by Levin and Mbamba (2004) showed that an expansion of agricultural production in Tanzania has the strongest potential effects in terms of employment and income generation, which would however benefit mostly the non-poor households, both in rural and urban areas. Despite such asymmetry, the growth of agricultural production still seems to imply the largest potential impact on poverty reduction. Furthermore, by selectively increasing total factor productivity (TFP) in agricultural productions, the study shows that the best growth prospects were offered by exportable crops, as these could lead to larger exportable surpluses. On the contrary, TFP increases in food crops would depress income growth, as food crops are mostly non tradable, and hence a production expansion, combined with a slow-down of domestic demand, would reduce prices, negatively affecting the poor rural households.

\section{The CGE model for Tanzania and data utilized}

The simulations presented in this paper are based on a single country computable general equilibrium model which was built as a modified version of the one presented in Lofgren et

\footnotetext{
2 According to the 2000/01 National Household Budget Survey (HBS, National Bureau of Statistics, 2002).

${ }^{3}$ In Tanzania the terms "cash crops" normally refers to exportable crops grown by farmers for cash, such as coffee, cotton, cashew nuts, tobacco, tea, etc.
} 
al. (2002). The framework is comparative static and assumes profit maximization on the supply side, and utility maximization on the demand side.

On the supply side, the model utilizes a constant elasticity of substitution (CES) assumption to determine the level of each activity from aggregate value added and aggregate intermediate inputs. Individual intermediate inputs are determined by fixed coefficients in relation to the aggregate intermediate inputs. Aggregate value added for each activity is defined as a CES function of factor inputs. Activities produce outputs of individual commodities, which are allocated to domestic and export uses via a constant elasticity of transformation (CET) function. Imports are assumed to be imperfect substitutes for domestic output, following the approach proposed by Armington (1969). Therefore, commodities available in the domestic market are modelled as composite goods, composed of domestic and imported differentiated products. Non- land capital - both in agriculture and in other activities - is assumed to be fixed in each sector at the base year level. Total arable land is assumed to be fixed, but substitution is allowed among agricultural activities, in light of price changes.

On the demand side, the model distinguishes between home self consumption, which flows directly from the activities to the households without including transaction costs, and marketed consumption, in which household purchase composite commodities which do include transaction costs and various indirect taxes. Two separate demand systems are included for home and marketed goods, both modelled as Linear Expenditure Systems (LES). Investment demand is defined as an adjustment coefficient times the physical amounts - akin to capital coefficients times the volume of total real investment - in the base period. This adjustment factor can be specified as either endogenous or exogenous depending on the closure rule.

The model includes explicitly a domestic trade sector, which collects the transaction costs associated with all marketed activities, and distinguishes three separate components of transaction costs, namely those involved in exporting goods, those for importing goods, and those required for selling into the domestic market. These margins enter the price formation equations in the form of exogenous transaction cost coefficients.

A representation of the public sector is included in the model, in which revenues accruing from value added, income, import and export taxes are balanced against public demand for government consumption and for investment. The public demand for commodities is determined by the demand for the product of a sector called public administration. Equilibrium conditions ensure clearance in the factor and the commodity markets.

Welfare will be measured through the concept of "money metric utility"(MMU) (Deaton, 1980), which compares the expenditure of a household under a simulated scenario, where the household has expenditure $Y$, and pays prices $p$, with the expenditure that the household would have to incur to obtain the same level of welfare as in the base period (denoted by 0 ) but assuming it had to pay the current prices $p$.

The simulations are based on the more recently available Social Accounting for Tanzania, provided by IFPRI, which refers to year 2001 (Thurlow and Wobst, 2003). The original SAM was aggregated to include 24 different activities and commodities, of which nine are crops, two are primary livestock activities, four are processed food and beverages, four are secondary sector activities, and five are services, including trade and administration ${ }^{4}$.

\footnotetext{
${ }^{4}$ The complete list of activities/commodities includes: maize, other cereals, beans, other cash crops, cassava and roots, coffee, cashew, other fruits and vegetables, other crops, livestock, fishing and hunting, mining, meats, processed grains, other processed foods, beverages, other secondary activities, construction activities, utilities, trade, hotels, transportation, other services, and public administration.
} 
In the factor market, the SAM utilized includes six types of labour, four of which can be considered as unskilled ${ }^{5}$, plus agricultural and non-agricultural capital, and land, which is employed only in agriculture. Concerning institutions, the private sector is represented by an aggregate enterprise entity, and by six types of households, three urban and three rural $^{6}$, plus a government sector. The SAM reports direct taxes, various types of indirect taxes, such as taxes on value added, taxes on factor use, imports tariffs and export subsidies.

Compared with microeconomic evidence inferred from independent micro survey work in Tanzania, the SAM provided by IFPRI included a relatively low level of transaction costs. This appeared to be the case for the domestic market, as well as for exports and imports. It appears that this is the case because the SAM includes as marketing cost only wholesale retail margins but not farmer to wholesale margins, which are the ones that concern us here, and which are the ones that are much larger than the wholesale retail ones ${ }^{7}$. Therefore, the SAM was modified accordingly. Given the absence of systematic information on transaction costs, it was decided to re-compute them as percentages of the values of the marketed as well as of the exported and imported commodities. The difference in the resulting income in the SAM was subtracted from the income of the respective producers, with the result that the whole SAM had to be rebalanced. For exported commodities it was assumed that the margin associated with transaction costs would amount to 50 percent of the marketed values. For imports the same margin was set at 20 percent of import values, and for domestic sales to households at 30 percent of purchased values.

In order to avoid losing useful information in the rebalancing process, it was decided, firstly, that the more reliable data would be maintained at their original level in the rebalancing. In this respect, the choice was to maintain data on foreign trade and all public sector transactions at their original level. Secondly, the rebalancing was implemented with different methods, in order to choose the output that would yield the smaller and more widespread changes in the original figures. The best performance was achieved by minimizing the sum of the squared residuals of the changes in the SAM elements.

Table 1 exhibits a summary of the structural characteristics of the Tanzanian economy as inferred from the (rebalanced) SAM of 2001. It can be seen that maize and cereals are large sectors as far as GDP is concerned but not large as far as trade is concerned. While agricultural exports are significant, the most important exportable sector is transport. The most important imported sector is that of secondary products. Among the export producing sectors, coffee and cashew are almost totally dependent on exports, while significant export propensity is exhibited by other cash crops and transport. There are large shares of most agricultural products that are not marketed. Despite small importance in total imports of maize and cereals their imports constitute a significant share of total consumption of these products. Finally the last column exhibits the domestic marketing margins as ratios to the marketed sales of the respective sectors after the rebalancing of the SAM.

\section{How do markets work? The closure rule in the Tanzania CGE model}

\footnotetext{
${ }^{5}$ The complete list of labour types includes: subsistence labour, child labour, non-educated male labour, noneducated female labour - which altogether form the unskilled group - plus educated male labour and educated female labour.

${ }^{6}$ The complete list of households includes, for both the rural and the urban sectors, poor, non-poor-noneducated, and non-poor-educated, distinguished on the basis of the s tatus of the reference person in the household.

${ }^{7}$ For instance, if the average price of coffee received by farmers as inferred from micro surveys is compared to the average (wholesale export) market price obtained in the Moshi auction the margin is largerthan 50 percent in Kilimanjaro, a region close to Moshi, and even higher for Ruvuma a region much further away from Moshi than Kilimanjaro.
} 
Any economy-wide model must include three basic macroeconomic accounts. The first is the government savings account, namely the difference between government revenue and expenditure. The second is the current account, which is the sum of the balance of trade and the balance on official and private remittances from abroad. The third and most fundamental one is the savings investment balance. The equilibrium of the econo my in any period requires that the value of total savings - the sum of domestic private and public savings and foreign savings, which is the negative of the current account balance - equals the value of total investments. This basic ex-post macroeconomic equilibrium is the result of the equilibrium in all product and factor markets. The macroeconomic closure is the way in which equilibrium in the various markets is achieved and hence results in the overall savings investments balance in the economy.

The macroeconomic closure in CGE models is a controversial one, as it involves debates and assumptions about how the overall macro-economy works. It has been a contentious issue in economics over the past decades, and the controversy between Keynes and the classical economists in the middle of the previous century was on this same type of issue. The debate in more modern times has pitted neoclassical macroeconomists versus those that believe that the real economies work more along Keynesian lines. Reviewing and discussing such extensive debate, or argue for one or another closure, is beyond the scope of this paper, and extensive reviews can be found in Rattso (1982), Robinson (1991) and Taylor (1990). Nevertheless, the issue cannot be avoided whenever one uses an aggregate economy-wide model, as one must eventually decide on what adjustment mechanism is more appropriate to the country context at hand.

The issue of how macroeconomic equilibrium in an economy is achieved, or the issue of closure, concerns both the way in which commodity and factor markets balance, as well as the way in which the government accounts and external accounts are balanced. Balancing the goods and factor markets can be done in essentially two ways. One is a flex price way, which assumes that total demand of a commodity or a factor is equal to total supply (which in turn can be fixed or variable in some pre-specified way) so that the commodity or factor price can adjust to clear the supply-demand equation. This is the standard neoclassical assumption about market functioning.

A second way is a fix-price one, which assumes that one or more quantity variables in the commodity and factor markets adjust to achieve supply-demand balance under fixed prices. The underlying rationale here, is that there is initial underutilization of a commodity (via preexisting stocks) or a factor (via some kind of unemployment) at the fixed prices, and hence when demand for a commodity or factor, for instance, increases, there can be more utilization of the good or factor without changing its price. Similarly when there is decreased demand the stock of the commodity increases or unemployment of the resource is the outcome without price changes.

It is probably fair to say that in the real world, commodity and factor markets most likely behave in an intermediate way. In other words, there are both price and quantity adjustments in achieving market equilibrium, and the amount of changes depend on the time horizon over which equilibrium is assumed to be achieved. In commodity markets, price adjustments are probably quite large in the short run, while in the longer run, given supply adjustments, the price adjustments tend to be moderated. The opposite is probably true of labor markets. In such markets there is probably some wage rigidity in the short run, and hence employment tends to vary. The longer the time horizon one considers, however, the more likely it is that price adjustments are larger. All this depends on the structure of each commodity and factor 
market, and it is not easy to identify which markets behave in one or another way. This is why there has been so much controversy, as the assumptions about how the real markets work is an empirical one and is based on one's knowledge of the economy, therefore views on these issues can legitimately differ, and are not easy to come to a definite empirical conclusion.

On the government side, the key behavioral issue is whether in the period of adjustment implicit in the modeled economy the government surplus or deficit is kept somehow fixed by active fiscal policy, namely by endogenous manipulation of some tax or other public revenue and expenditure instruments -or the fiscal policy is assumed to be passive, with exogenous tax and other expenditure rates and levels, and an endogenous government surplus/deficit which maybe accommodated by monetary or other domestic and international borrowing adjustments. On the external side, the key behavioral issue is whether the exchange rate adjusts to achieve given external availability of foreign exchange, and hence a fixed current account balance, or whether the exchange rate is kept fixed, and the current account passively adjusts by additional foreign exchange resources through foreign borrowing, or by accumulating foreign exchange reserves. On the investment side, the key behavioral issues concern the level of real investment (private and public), and whether this is determined by aggregate available savings in a classical way, or it is set by exogenous forces (such as the Keynesian private "animal spirits" and government policy), with savings adjusting endogenously to achieve the required amount of investment.

Concerning Tanzania the following assumptions will be made in our preferred closure for the CGE model, based on empirical evidence and our knowledge of the economy. Concerning commodity markets, we shall assume that they clear in a flex price way. In other words we assume that all commodity prices adjust to make supplies equal demands. This is a standard assumption in most CGE models, and we believe that it is appropriate in the context of a low income economy such as Tanzania, in a post-adjustment phase, where there are no essential price controls on most products. Concerning factor markets, however, we depart significantly from standard CGE model practice, as far as labor markets are concerned. It is well known, and Tanzania is no exception, that most low income countries have excess of unskilled labor and shortage of skilled labor. This suggests that skilled labor wages are more responsive to changes in supply and demand, while unskilled wages are less so. We indeed assume that in Tanzania the wages of all unskilled labor classes are fixed in real terms, while wages of skilled labor classes are flexible and respond to supply and demand.

Concerning the behavior of investment we side with the classical view that investment is determined by available savings, as we believe that savings, especially private savings are a major constraint to investment in an economy such as Tanzania. Concerning the foreign sector, we assume that exchange rate is flexible, while the availability of foreign savings (namely foreign loans and grants) is fixed. This seems to fit well with the post adjustment period in Tanzania. Finally, we assume that the government budget is endogenously determined. In other words we assume that the government does not have the short term ability to change taxes and other fiscal instruments to keep the public deficit at a fixed level.

While we use this closure rules as the basis of our simulations, we also examine the implications of trade liberalization under a variety of other closures to indicate the different impacts that could be inferred under different structural and economic adjustment

\section{Trade liberalization under different closure rules}

There is considerable debate concerning the impacts of trade liberalization in developing economies, and the purpose of this section is to explore the extent to which closure rules can 
account for some part of the debate. While we explained above our preferred closure, it is instructive to compare the results of our simulations under different closure assumptions. In the sequel we present the results of a series of simulations designed to explore the impact of a 50 percent cut in all import tariffs on the Tanzanian economy.

In the simulations presented in this section the same CGE model is run with a total of seventeen different types of closures summarized in Table 2. In the first closure, we assume that all commodity and factor markets are flex-price. This is the standard approach in almost all CGE-based analyses, implying that the labor market is characterized by variable factor returns under fixed total factor supplies. The external sector is assumed to balance via a flexible exchange rate, under the hypothesis that foreign savings are fixed. Government savings are endogenously determined, as tax rates are assumed fixed, and do not adjust to maintain a constant government balance. Finally, this first closure postulates that the level of real investment is determined by the available savings in the economy, following in this sense the neoclassical approach.

Closure 2 modifies this last hypothesis, and makes total real investment exogenous, while endogenizes the domestic saving rates of non-governmental institutions (enterprises and households), that needs to match the initial level of investment. Closure 3 maintains all the assumptions of the first closure, except that the exchange rate is assumed to be fixed, and the level of foreign savings is flexible and determined endogenously.

In the following four closures - closures 4 to 7 - we allow for different types of quantity adjustments in the labor markets. The modeling of these markets has been shown to be particularly important (Taylor, 1990), especially in terms of projected growth. When employment is allowed to vary beyond fixed levels in the model, in fact, the economy is allowed to generate additional value added, and hence GDP. Moreover, allowing quantity adjustment implies that unemployment has to be postulated in the base run. In other words, it is assumed that some unutilized or underutilized labor is available in the economy at fixed real wages.

It is probably reasonable to assume, in general, that labor supply is mot fixed, and that it can be stimulated by increases in real wage rates, either by inducing people to work more, or through increased labor market participation. In many developing economies there is in fact considerable hidden unemployment or underemployment, even at current real wages. This suggests that there may be a potential for increasing employment even without increasing real wages. In Tanzania, there are large subsistence and "informal" activities that could be sources of unskilled labor at fixed "subsistence" (or very low) unskilled wages a-la Lewis. For instance, Sarris, Savastano and Christiaensen (2006) found that the marginal product of family labor in farm production is considerably smaller than the market wage of agricultural labor for all the classes of rural households that they considered. This implies the presence of considerable excess labor among farm households. Also in the skilled labor market, quantities may not necessarily be fixed, since skilled workers too could increase the level of their participation when additional opportunities arise. Hence a fix-price assumption in some parts of the labor markets in Tanzania is not unreasonable.

To explore the consequences of the assumptions in the labor market, closure 4 postulates fixed real wages for all labor categories - there are six labor types in the SAM - and hence endogenous levels of employment in all labor types. As it is not a-priori clear whether the fix price assumption is the more appropriate in the skilled or unskilled labor category, closure 5 assumes that the four types of unskilled labor markets exhibit fixed prices, while the two skilled labor categories exhibit flexible wages under the assumption of fixed labor supplies. This is supposed to simulate the situation of "unlimited supplies of unskilled labor", while 
skilled labor is in fixed supply. Closure 6 reverses this setting, and assumes that all unskilled labor types are flex price, while all skilled labor types are fix price.

Closure 7 is similar to closure 1, except that it allows for full substitution between all unskilled labor categories, as well as full substitution among all skilled labor categories. In other words we fix the wage differentials among the wages of the various unskilled labor types, but we allow the overall level of "unskilled wage" to adjust to a fixed supply of total unskilled labor, which is equal to the sum of the base levels of unskilled labor supply in all categories. We assume the same among the two skilled labor types. This closure rule reproduces full substitutability among labor types within the same labor skill level.

Closure 8 combines the assumption of fixed real wages already explored in rule 4 - implying endogenous levels of employment - with flexibility of foreign savings, and a fixed exchange rate, as explored in rule 3 .

The following six closures - from 9 to 14 - assume that the government runs an active fiscal policy, while being unwilling to run an endogenous budget level of surplus or deficit. This implies that some tax rates must become endogenous, while the government budget is assumed to be predetermined at the level of the base run. Particularly, closures 9, 11 and 13 postulate that the direct tax rates are endogenous, while the indirect ones are set exogenously; the contrary applies, instead, to closures 10,12 and 14. These assumptions on public finance are also combined with the hypotheses concerning the labor market and the external financing already described above. Therefore, closures 9 and 10 assume flexible wages together with a flexible exchange rate; closures 11 and 12 postulate the presence of fixed wages and unemployment with a flexible exchange rate; and rules 13 and 14 assume fixed wages, but with fixed exchange rate and endogenous foreign saving.

Finally, the last three closures, numbers 15, 16, and 17, adopt in the labor market what is probably the more realistic approach for the Tanzanian case. In the unskilled labor market we apply the same approach of closure 5, namely fixed wages for all unskilled labor classes and quantity adjustments. For the skilled labor classes we adopt the assumption of closure 7, namely that the total amount of skilled labor is fixed, and the overall average wage of this class adjusts to the supply, but there is a fixed differentials among the wages of the two skilled labor classes, and hence substitution between the two skilled classes. This approach reflects the idea that the more skilled segments of the labor market are characterized by a limited supply of workers, while the unskilled labor categories - including unskilled, child and subsistence workers - are instead assumed to be characterized by a variable degree of engagement in the labor market and/or by the presence of idle labor, which is willing to enter the market for a fixed wage close to subsistence. In the last three closures this criterion is combined with exogenous taxation - closure 15 - and with endogenous direct and indirect taxations - closures 16 and 17 respectively. As mentioned earlier our preferred closure for Tanzania is closure 15 .

The simulations presented in Section 5 are aimed at showing, among other points, the extent to which the assumptions embedded in the closure rules can make a difference in terms of the results. In turn, this helps in identifying the results which are relatively more robust to changes in the basic assumptions.

Table 3 reports the main results of the scenario, in which all tariffs are cut by 50 percent, implemented under the 17 different closures described above. This policy change, akin to significant trade liberalization, produces almost no changes in GDP under the closures that postulate fixed supplies of labor. It produces small increases in GDP under closures that assume fixed wages. The largest increase in GDP is shown under our preferred scenario 15. 
On the foreign trade front, it implies a depreciation of the exchange rate under all closures, except of course with the ones that assume a fixed exchange rate. Under all closures the economy experiences a significant expansion of agricultural and total imports, and a marginal increase (which under some closures is a decrease) of agricultural and total exports. Real aggregate investment (private and public) seems to follow the changes of public savings, which are a large component of total savings.

The policy change has a strong negative impact on public savings, under all closures that allow government savings to be determined endogenously, which are closures 1 to 8 , and closure 15. Another variable which appears to be affected significantly by the closure is agricultural trade. The percentage changes in imports seem to be affected by the assumption of fixed or variable foreign savings. This suggests that the consequences of trade liberalization should not be assessed independently from the exchange rate policy and the conditions that determine the availability of foreign exchange in the country.

Concerning labor, all closures that assume the presence of unemployment show minor GDP percentage changes from the base run. It is worth noticing that, in the closures with unemployment in all labor classes, while the changes in total skilled labor are systematically positive under all closures, those for unskilled labor vary considerably. This is an important result, since it indicates the extent to which cutting tariffs in Tanzania is or is not pro-poor. More in detail, employment of unskilled labor is reduced by the cut in the tariff when we budget neutrality, and hence allow taxation to compensate for the reduction in Government's saving, that is in closures 11-14, 16-17. For Tanzania, this implies that if the government wishes to keep budget neutrality while reducing a source of public revenue such as import tariffs, the increased taxation will reduce employment in the informal sector, and even more so if we postulate that the stock of educated manpower is fixed and operates with variable wages - as it is the case of closures 16 and 17. But more in general, the result indicates that the effects of a cut in import tariffs can vary widely depending on the domestic policy framework, and on how the Government will compensate for the revenue loss determined by the tariff reduction.

Table 4 shows how the reduction in tariffs affects welfare across the six household groups reported in the SAM, under the various closure rules. It is worth emphasizing how the differences arising from the assumptions embedded in the closures can determine a switch from a positive to a negative outcome for some households. Particularly evident is the fact that welfare appears to be reduced for the poor rural households in all closures which assume budget neutrality and an endogenous adjustment of direct or indirect taxation (closures 9-14). A relatively stronger reduction in welfare takes place in the more well-off urban households when taxation is adjusted to budget neutrality without allowing employment to vary within the skilled labor market segment, as it is the case of closures 16 and 17. The stronger welfare increases are shown by closures 8 and 15 especially for the better off urban households. For the latter closure, this stems form the relatively strong increase in employment shown in Table 4, arising from the assumption of fixed wages in the skilled workers. For closure 8, instead, the welfare increase appears related to the GDP growth, which is the highest across all closures, and stems from the combination of increased employment and trade. More in general, the evidence on welfare shows that the closure rule can indeed affect the distributional implications of any policy simulation exercise.

The results of this section indicate, much like the previous literature indicated, that it is quite important to select the appropriate closure scenario when simulating a CGE model.

\section{Results of policy and other structural and exogenous shock scenarios}


In this section we return to our preferred closure for the Tanzania case, namely closure 15 in the previous section and conduct a series of experiments to ascertain the relative impact of trade liberalization versus other policy or exogenous changes.

In terms of scenarios, the simulations presented are aimed at exploring the implications of different types of changes in the areas of marketing margins, trade policy, and exogenous environment in stimulating growth as well as welfare improvements. The following four scenarios have been analyzed, which are also summarized in Table 5:

1. an exogenous 10 percent decrease in the marketing margins, designed to explore the impacts of investing in marketing infrastructure;

2. a 50 percent cut in all import tariffs;

3. combines scenario 1 and 2 , namely tariff cuts in addition to marketing margin decreases

4. a 10 percent increase in export crop prices;

5. a 10 percent increase in the import prices of food and agricultural imports;

6. a 10 percent increase in export crop prices combined with a 10 percent increase in the import prices of food and agricultural imports;

7. The price increase implied in scenarios 4 and 5 and in addition the tariff cuts implied in scenario 2. This is a scenario that maybe expected from a multilateral trade liberalization, albeit the numbers are quite arbitrary and only indicative

Table 6 reports the results of these experiments for a set of macro variables including the aggregate real GDP at factor cost; agricultural and total imports and exports, aggregate investment, employment of unskilled and skilled labor, and the exchange rate. Table 7 reports the results for the welfare of the six types of households

In the first scenario (MARG DECR), the 10 percent decline in the marketing margins raises producer prices of agricultural commodities, including those of the exportable crops, whose production expands, inducing significant increases in exports. Given the assumption of variable employment in the unskilled workforce, the increased prices imply additional agricultural production and income. Part of this flows into home consumption, but also demand for domestic products, and substitutes a part of agricultural imports, while increasing imports (and consumption) of non agricultural and hence more income-sensitive goods. This happens notwithstanding the depreciation of the exchange rate, which boosts the production of import-competing goods, particularly manufactures in this case. In turn, the positive effects on both production and consumption explain the good performances of GDP and investment. The latter is helped by larger government revenues from tariffs on increased imports. The aggregate employment of unskilled labour increases considerably, and this is the factor that boosts GDP. Considering household welfare (Table 7), this scenario implies significant and quite generalized improvements in welfare of all types of households, and this is the result of increased demand for unskilled labour.

The second scenario (TARCUT), implies a 50 percent reduction in all tariffs, and has already been examined but in the context of different closures, rather than in comparison with other scenarios. Under this simulation the level of Government savings is significantly reduced, by almost 50 percent as a consequence of the reduced revenues (Table 6). and this has detrimental effects on aggregate investment. As expected, imports and exports increases particularly on the import side, despite a 1.6 percent depreciation of the exchange rate, the latter accounting for the good performance of exports. At the same time, the smaller demand 
for domestic goods leads to a lower level of investment. However, GDP still grows, although to a small extent, as a consequence of the small increased level of employment of the unskilled workforce. In terms of welfare (Table 7) the scenario shows mixed results. Net gainers are the urban poor and the less educated households, together with the better off rural households. The increased employment of the unskilled workforce explains the result for the urban poor households, while the improved position of the rural more educated households stems from the increased exports, which are mostly made of agricultural cash crops such as coffee and cashew. However, it appears that one of the fears of trade liberalization is realized, namely unequal benefits for households, and especially reductions in welfare of the rural poor.

The third scenario (MARG \& TARCUT) combines the previous two, that is, it shows what would be the effect of reducing tariff while simultaneously reducing marketing margins. It is worth noticing that under this third scenario the effects on GDP, on trade and on the level of employment are higher than the sum of the effects of the two previous scenarios (Table 6); moreover the reduction in public savings - arising from the decreased tariff revenue - is partly counteracted by the increased tax revenues on production and consumption. Altogether, this means that the combination of tariff and marketing margin reductions yields positive interactive effects. Consistently, also in terms of welfare this scenario exhibits a generalized improvement across household types (Table 7), particularly for the better of rural household, as a consequence of the large increase in agricultural exports.

The fourth scenario (EXP PR INCR) is one under which world prices for Tanzanian export crops increase by 10 percent. This involves increases in the prices of the four sectors that produce the bulk of Tanzanian agricultural exports, namely coffee, cashew nuts, other cash crops such as cotton, and oilseeds, and fishing and hunting. The simulation produces a small increase in GDP (Table 6) together with a significant exchange rate appreciation, as expected under a fixed foreign exchange availability constraint. Agricultural exports increase only slightly, and total exports decrease due to the restructuring of the export producing sectors, while total imports increase to keep foreign savings constant. Total investment increases marginally under this scenario, and public savings deteriorate slightly, following a production shift towards export crops, which are less taxed. Thus, the small increase in total investment comes about because of an increase in private rather than public savings. In terms of welfare (Table 7) also this scenario, like the previous one, implies a generalized improvement, which in this case is particularly significant for the better off households, both urban and rural.

The fifth scenario (IMP PRINCR) simulates an increase in the world prices of the main imported agricultural and food products, involving a 10 percent increase in the border prices of five sectors, namely other cereals, other crops, processed grains, beverages, and other food. Also this scenario leads to a slight GDP expansion, to a minor appreciation of the exchange rate, to a significant decrease of agricultural imports, and to a decrease in total imports, as well as in agricultural and total exports. Total investment appears to increase marginally, as do public savings. On the welfare front (Table 7), this scenario favours the urban poor and uneducated households, together with the better off rural ones. However, in general there does not appear to be much negative impact from world price increases of food and agricultural imports, due also to the smaller share of imports in the major staple foods. This conclusion bodes well for the impact on Tanzania from a multilateral trade liberalization that may increase world prices of food and agricultural products.

The sixth scenario (IMP EXP PR INCR) combines the previous two, to simulate a 10 percent increase in the border prices of all the main agricultural products, both the five main import food products and the four sectors that produce the bulk of Tanzanian agricultural exports. In 
terms of policy, this scenario resembles - in optimistic terms - the outcome of a multilateral trade liberalization, leading to some kind of widespread increase in world prices. The results appear to induce growth in employment, investment and welfare (Tables 6 and 7). A modest GDP growth arises together with minor changes in the trade pattern; whereas a more significant change appears in the level of unskilled labour. Welfare increases in all rural households, as well as in the poorer urban group, largely as a result of the increased employment in the lower labour market segments. The policy implication of the scenario is simple: increased world market prices without obligations to cut its own tariffs would produce considerable expansion in Tanzanian agriculture; and such expansion would be pro-poor, as confirmed also by the analyses reviewed in Section 3.

The seventh scenario (MULT TRADE LIB) that combines scenarios 2, 5 and 6 exhibits stronger GDP growth than any of the other scenarios and larger increases in agricultural imports. However, it implies significant reductions in aggregate investment due to the large reduction in public savings. In terms of welfare, it is still the case that the rural poor and uneducated are very little or negatively affected, implying that multilateral type of trade liberalization will have rather adverse distributional impacts.

The scenarios that yielded the more significant results in terms of the macro variables as well as welfare improvements are the ones in which marketing margins are reduced. These appear to dominate by significant amounts the different trade policy scenarios, and suggest that gains from infrastructure and transaction cost reducing interventions can have more important growth and pro-poor impacts. This implies that the aid for trade initiative that is supposed to, among other, help reduce transactions cost and improve tradable infrastructure is probably more important and should be given priority over the trade liberalization in developing and especially lest developed countries.

Ii is interesting to explore whether the effects of trade liberalization change linearly with the degree of liberalization. To this end, graph 1 traces the effects of progressive tariff reductions on GDP, trade, investment and labour, following the values reported in Table 8. The percentage changes in these variables appear to be linearly increasing with the deepening of the cut in the tariffs. Public savings become negative under a scenario in which agricultural tariffs are completely eliminated. Consistently, welfare results also follow a very regular pattern (Graph 2), in which the relatively worse off rural households suffer increasing losses from progressive agricultural tariff reductions, while all the others benefit, to a greater extent.

The same type of evidence is presented also with reference to the reduction in the marketing margins. In this case, scenarios were built assuming progressive reduction of the marketing margins from 5 percent to 20 percent; wider reductions would not allow the model to converge. The evidence (Graph 3) in this case shows that additional reductions in marketing margins would yield more than proportional changes in some key variables, such as GDP, exports and unskilled labour. For instance, the marginal percentage increase in GDP between the 5 percent and the 10 percent scenarios is 1.9 , while it becomes 2.6 between the 15 percent and the 20 scenarios; the same applies to unskilled labour, where the marginal increase in employment is 8.2 between the 5 percent and the 10 percent scenarios, while it is 12.2 between the 5 percent and the 10 percent scenarios.

Welfare results (Graph 4) are consistent with this picture. Poor rural households appear to gain less than their urban counterparts, but for all households types, doubling the decrease in marketing margins imply more than doubled welfare increases.

\section{Sensitivity analysis}


The sensitivity of the results presented above was analyzed in several ways. Concerning marketing margins, as mentioned these were increased in the base SAM compared to the original SAM supplied by IFPRI, on the basis of additional micro-level information on the difference between farm-gate and wholesale prices. The same policy scenarios presented above in the last section were also run on the original dataset supplied by IFPRI. It is worth underlining that despite the relative strength of the effect of a reduction in the marketing margins compared to that of the tariff cut proved to be robust to the change in the initial size of the margins. We believe that this is an important check, which rules out the possibility that the economy-wide effect of a reduction in the margins arises only from their size, which we overstated compared to the original dataset supplied by IFPRI.

Concerning the closure rules, the experiments presented in the previous section were run with all the 17 closures reported in Table 1. Also in this case, the relative effects of marketing margins reduction vis a vis tariff reductions turned out to be fairly robust to changes in the assumptions, despite the fact that the distributional impacts in the economy varied considerably, following a pattern similar to the one highlighted in section 4 , in the discussion of the results for the different closures.

Concerning the parameters, the major unknown parts in CGE models of this type, which are calibrated to a base data set, are the substitution and transformation elasticities, particularly those governing the substitution in consumption between domestically produced and imported commodities, the substitution in production between domestic and exportable products, and the substitution among the factors in the production across the activities. Such parameters determine the extent to which substitutions occur within the economy, and they are expected to be larger the longer the time horizon assumed as underlying the simulations. As it is not easy to pinpoint the type and extent of adjustment that is possible in an economy, in order to explore the sensitivity of the results to the parameter employed we repeated all the experiments indicated earlier with the following assumptions.

Firstly, we run the model with the Armington elasticities of substitution between domestic and imported commodities set at 50 percent of their original value, while all the other parameters were unchanged. Secondly, we increased the same elasticities by 50 percent of their base level values. The third and the fourth sensitivity runs assumed the same changes in the elasticities of transformation in production between domestic and exported commodities, while all other parameters were unchanged. The fifth and the sixth experiments assumed that the elasticities of substitution between factors in the production in the various activities were 25 percent lower and 25 percent higher than their original values respectively, with all the other parameters unchanged.

Due to space reasons, we do not report all these results, which are available from the authors upon request. In general, they do not exhibit significant changes compared to the results obtained with the base parameter values.

\section{Concluding remarks}

The result that appears to derive from our scenarios is that the highest poverty reduction under all closure rules is the one in which marketing margins are decreased. We have described more extensively the simulations implying a 10 percent reduction in the economy wide trade costs, but we saw that the benefit arising from this change increase more than proportionally if we double the size of this shock. This implies that all households, but particularly the rural poor could gain substantially from a change in this area. While the exact size of GDP growth and of the welfare improvements depend upon the closure rule adopted, there appear to be 
few doubts that a reduction in marketing margins would be an efficient investment policy choice for Tanzania.

By contrast, all scenarios assuming significant further trade liberalization do not seem to produce significant GDP changes, nor do they produce any significant changes in household welfare, even when large degrees of liberalization are assumed. If anything, tariff cuts produce a large decline in public revenues, which in turn affects negatively total available savings in the economy and hence the volume of real investment. We should conclude, therefore, that trade liberalization does not appear to be a panacea for growth and poverty alleviation, at least in Tanzania.

Another major methodological conclusion that obtains from the empirical results is that the nature of the closure rules makes a large difference on the results of the scenarios. It has been shown that the outcome of individual crucial variables such as household welfare, GDP and trade related variables can move in opposite directions depending on the closure rule assumed. In turn, this, highlights the fact that the evaluation of appropriate growth-enhancing and poverty-reduction policies cannot be done without a thorough discussion and consideration of the way in which the various parts of the economy adjust to new signals. It appears that this especially applies to the functioning of the labor market, and in particular to whether the labor market adjusts in a flex-price mode, namely via real wage adjustments in combination with low employment variability, or in a more fix price mode, namely with real wages relatively stable and employment adjustments. Microeconomic considerations for Tanzania seem to support the fix-price mode of adjustment, but certainly more analysis and research is required to assess the functioning of the various types of labor markets within the economy. Similarly any empirical analysis using CGE models, whether national of global, should devote considerable effort at understanding and incorporating in the model structure the nature of the different closure rules that seem prevalent in different types of economies, as they may make a considerable difference in the results 


\section{References}

Ackerman, Frank (2005). The Shrinking Gains from Trade: A Critical Assessment of Doha Round Projections, GDAE Working Paper No. 05-01

Armington, P.A. (1969), "A Theory of Demand for Products Distinguished by Place of Production" International Monetary Fund Staff Papers 16

Arndt, C. H. Tarp Jensen, S. Robinson, and F. Tarp (2000) "Marketing margins and agricultural technology in Mozambique", The Journal of Development Studies, vol. 37(1), pp. 121-137

Deaton, A., 1980. The Measurement of Welfare. Theory and Practical Applications. Living Standards Measurement Study, Working Paper No. 7, World Bank, Washington DC.

Delgado, C., N. Minot, and M. Tiongco (2003) "Evidence and implications of non-tradability of food staples in Tanzania 1983-1998" International Food Policy Research Institute, Markets Trade and Institutions Division, MTID Discussion Paper No. 72

Government of the United Republic of Tanzania, the World Bank, and International Food Policy Institute, (2000). Agriculture in Tanzania since 1986: Follower or Leader of Growth?. A World Bank country study.

Kilima, F.T.M. (2006) "Are price changes in the world market transmitted to markets in less developed countries? A case study of sugar, cotton, wheat, and rice in Tanzania", Department of Agricultural Economics and Agribusiness, Sokoine University of Agriculture, IIIS Discussion paper No 160, Morogoro, Tanzania,

Levin, J., and R. Mbamba (2004), "Economic growth, sectoral linkages and poverty reduction in Tanzania", World Bank, background paper for the Tanzania CEM.

Lofgren, H. R. Lee Harris, R. and S. Robinson. (2002) "A Standard Computable General Equilibrium (CGE) Model in GAMS" International Food Policy Research Institute, Microcomputers in Policy Research No 5

Minot, N. (2005) "Are poor, remote areas left behind in agricultural development: The case of Tanzania", International Food Policy Research Institute, Markets Trade and Institutions Division, MTID Discussion Paper No. 90

National Bureau of Statistics, 2002. Household Budget Survey 2000/01, Dar es Salaam.

Rattso, J. (1982) "Different macroclosures of the original Johansen model and their impact on policy evaluation”, Journal of Policy Modeling vol. 4(1) pp. 85-97

Robinson, S. (1981) "Macroeconomics, financial variables, and computable general equilibrium models", World Development vol. 19, pp. 1509-1525

Sarris, A., S. Savastano, and L. Christiaensen (2006) "Agriculture and poverty in commodity dependent African countries: A rural household perspective from the United Republic of Tanzania" FAO Commodities and Trade Technical Paper No. 9.

Stifel, D., B. Minten, and P. Dorosh (2003) "Transactions costs and agricultural productivity: Implications of isolation for rural poverty in Madagascar" International Food Policy Research Institute, Markets and Structural Studies Division, MSSD Discussion Paper No. 56.

Taylor, L. (1990) "Structuralist CGE models" in L. Taylor, (editor) Socially Relevant Policy Analysis. Cambridge, Mass., USA, MIT Press. 
Taylor L. and R. von Arnim (2006). Modeling the Impact of trade liberalization. A critique of Computable General Equilibrium Models Oxfam International Research Reports, May 2006

Thurlow, J. and P. Wobst (2003) "Poverty-focused Social Accounting Matrices for Tanzania", International Food Policy Research Institute, Trade and Macroeconomics Division, TMD Discussion Paper No. 112.

Wobst, P. (2003) "The impact of domestic and global trade liberalization on five southern African countries", The Journal of Development Studies, vol. 40(2), pp. 70-92 
Table 1. Production and trade structure of the Tanzanian economy in 2001.

\begin{tabular}{|c|c|c|c|c|c|c|c|}
\hline & $\begin{array}{c}\text { Share in } \\
\text { total value } \\
\text { added } \\
\text { (percentag } \\
\text { e) }\end{array}$ & $\begin{array}{c}\begin{array}{c}\text { Share in } \\
\text { total } \\
\text { exports } \\
\text { (percentage }\end{array} \\
\text { ) }\end{array}$ & $\begin{array}{c}\text { Share in total } \\
\text { imports } \\
\text { (percentage) }\end{array}$ & $\begin{array}{c}\text { Share of } \\
\text { exports in } \\
\text { production } \\
\text { (percentage) }\end{array}$ & $\begin{array}{c}\text { Share of marketed } \\
\text { production in total } \\
\text { production } \\
\text { (percentage) }\end{array}$ & $\begin{array}{c}\text { Share of imports } \\
\text { in total domestic } \\
\text { consumption } \\
\text { (percentage) }\end{array}$ & $\begin{array}{c}\text { Ratio of } \\
\text { domestic } \\
\text { margin to } \\
\text { marketed } \\
\text { production } \\
\text { (percentage) }\end{array}$ \\
\hline maize & 9.9 & 0.1 & 0.8 & 0.2 & 48.2 & 3.6 & 13.3 \\
\hline other cereals & 5.6 & 0.2 & 2.0 & 0.5 & 76.7 & 7.7 & 4.2 \\
\hline beans & 2.3 & 0.1 & 0.0 & 0.6 & 73.6 & 0.0 & 25.6 \\
\hline other cash crops & 4.6 & 10.2 & 2.5 & 22.1 & 93.3 & 8.8 & 7.3 \\
\hline cassava and roots & 3.6 & 0.0 & 0.0 & 0.0 & 40.2 & 0.0 & 31.4 \\
\hline coffee & 0.8 & 7.3 & 0.0 & 92.7 & 96.0 & 0.0 & 1.1 \\
\hline cashew & 1.0 & 7.2 & 0.0 & 98.6 & 100.0 & 0.0 & 0.0 \\
\hline $\begin{array}{l}\text { other fruits and } \\
\text { vegetables }\end{array}$ & 6.6 & 2.1 & 0.4 & 6.9 & 65.9 & 2.0 & 31.8 \\
\hline other crops & 0.8 & 0.3 & 0.0 & 9.5 & 58.6 & 0.3 & 25.8 \\
\hline livestock & 3.3 & 0.5 & 0.1 & 2.4 & 83.7 & 1.1 & 13.7 \\
\hline $\begin{array}{l}\text { fishing and } \\
\text { hunting }\end{array}$ & 7.7 & 5.4 & 0.0 & 13.3 & 77.5 & 0.1 & 28.6 \\
\hline mining & 1.5 & 1.5 & 0.7 & 12.7 & 100.0 & 9.0 & 4.2 \\
\hline meats & 2.3 & 0.0 & 0.2 & 0.2 & 75.1 & 1.5 & 40.8 \\
\hline processed grains & 0.7 & 0.5 & 0.8 & 1.0 & 100.0 & 2.3 & 33.1 \\
\hline foods & 2.0 & 0.5 & 3.7 & 1.3 & 97.3 & 14.8 & 44.0 \\
\hline beverages & 0.9 & 0.1 & 0.8 & 0.5 & 95.9 & 8.2 & 38.6 \\
\hline other secondary & 6.2 & 3.3 & 62.7 & 1.6 & 100.0 & 52.9 & 3.0 \\
\hline utilities & 1.7 & 0.0 & 0.0 & 0.0 & 100.0 & 0.0 & 0.0 \\
\hline construction & 4.5 & 0.0 & 0.1 & 0.0 & 100.0 & 0.3 & 0.0 \\
\hline trade & 10.5 & 0.0 & 0.0 & 0.0 & 100.0 & 0.0 & 0.0 \\
\hline hotels & 2.6 & 0.0 & 0.0 & 0.0 & 100.0 & 0.0 & 0.0 \\
\hline transportation & 5.8 & 44.3 & 19.5 & 53.7 & 100.0 & 36.4 & 0.0 \\
\hline other services & 9.0 & 10.9 & 4.7 & 7.4 & 74.9 & 4.9 & 0.0 \\
\hline administration & 6.2 & 5.5 & 0.9 & 4.4 & 100.0 & 1.1 & 0.0 \\
\hline
\end{tabular}

Source. Computed by authors 
Table 2. Assumptions of the different closure rules simulated

Unskilled
labor market $\begin{gathered}\text { Skilled labor } \\ \text { market }\end{gathered}$ Exchange rate Investment Government savings

\begin{tabular}{|c|c|c|c|c|c|}
\hline Closure 1 & Flex price & Flex price & Flexible & Savings driven & $\begin{array}{l}\text { exogenous taxes } \\
\text { endogenous savings }\end{array}$ \\
\hline Closure 2 & Flex price & Flex price & Flexible & Exogenous & $\begin{array}{l}\text { exogenous taxes } \\
\text { endogenous savings }\end{array}$ \\
\hline Closure 3 & Flex price & Flex price & Fixed & Savings driven & $\begin{array}{l}\text { exogenous taxes } \\
\text { endogenous savings }\end{array}$ \\
\hline Closure 4 & Fix price & Fix price & Flexible & Savings driven & $\begin{array}{l}\text { exogenous taxes } \\
\text { endogenous savings }\end{array}$ \\
\hline Closure 5 & Fix price & Flex price & Flexible & Savings driven & $\begin{array}{c}\text { exogenous taxes } \\
\text { endogenous savings }\end{array}$ \\
\hline Closure 6 & Flex price & Fix price & Flexible & Savings driven & $\begin{array}{l}\text { exogenous taxes } \\
\text { endogenous savings }\end{array}$ \\
\hline Closure 7 & $\begin{array}{l}\text { Flex price. Full } \\
\text { substitution } \\
\text { within class }\end{array}$ & $\begin{array}{l}\text { Flex price. Full } \\
\text { substitution } \\
\text { within class }\end{array}$ & Flexible & Savings driven & $\begin{array}{c}\text { exogenous taxes } \\
\text { endogenous savings }\end{array}$ \\
\hline Closure 8 & Fix price & Fix price & Fixed & Savings driven & $\begin{array}{l}\text { exogenous taxes } \\
\text { endogenous savings }\end{array}$ \\
\hline Closure 9 & Flex price & Flex price & Flexible & Savings driven & $\begin{array}{l}\text { endogenous direct taxes } \\
\text { and fixed savings }\end{array}$ \\
\hline Closure 10 & Flex price & Flex price & Flexible & Savings driven & $\begin{array}{l}\text { endogenous indirect } \\
\text { taxes and fixed savings }\end{array}$ \\
\hline Closure 11 & Fix price & Fix price & Flexible & Savings driven & $\begin{array}{l}\text { endogenous direct taxes } \\
\text { and fixed savings }\end{array}$ \\
\hline Closure 12 & Fix price & Fix price & Flexible & Savings driven & $\begin{array}{l}\text { endogenous indirect } \\
\text { taxes and fixed savings }\end{array}$ \\
\hline Closure 13 & Fix price & Fix price & Fixed & Savings driven & $\begin{array}{l}\text { endogenous direct taxes } \\
\text { and fixed savings }\end{array}$ \\
\hline Closure 14 & Fix price & Fix price & Fixed & Savings driven & $\begin{array}{l}\text { endogenous indirect } \\
\text { taxes and fixed savings }\end{array}$ \\
\hline Closure 15 & Fix price & $\begin{array}{l}\text { Flex price. Full } \\
\text { substitution } \\
\text { within class }\end{array}$ & Flexible & Savings driven & $\begin{array}{l}\text { exogenous taxes } \\
\text { endogenous s avings }\end{array}$ \\
\hline Closure 16 & Fix price & $\begin{array}{c}\text { Flex price. Full } \\
\text { substitution } \\
\text { within class }\end{array}$ & Flexible & Savings driven & $\begin{array}{l}\text { endogenous direct taxes } \\
\text { and fixed savings }\end{array}$ \\
\hline Closure 17 & Fix price & $\begin{array}{c}\text { Flex price. Full } \\
\text { substitution } \\
\text { within class }\end{array}$ & Flexible & Savings driven & $\begin{array}{l}\text { endogenous indirect } \\
\text { taxes and fixed savings }\end{array}$ \\
\hline
\end{tabular}

Source. Authors' calculations 
Table 3. Results of a 50 percent tariff cut with different closure rules

(percentage change from base)

\begin{tabular}{|c|c|c|c|c|c|c|c|c|c|c|}
\hline closures & GPD & $\begin{array}{l}\text { agricultural } \\
\text { import }\end{array}$ & $\begin{array}{l}\text { total } \\
\text { imports }\end{array}$ & $\begin{array}{l}\text { agricultural } \\
\text { export }\end{array}$ & $\begin{array}{l}\text { total } \\
\text { exports }\end{array}$ & $\begin{array}{l}\text { aggregate g } \\
\text { investment }\end{array}$ & $\begin{array}{l}\text { government } \\
\text { savings }\end{array}$ & $\begin{array}{l}\text { skilled } \\
\text { labour }\end{array}$ & $\begin{array}{c}\text { unskilled } \\
\text { labour }\end{array}$ & $\begin{array}{c}\text { exchange } \\
\text { rate }\end{array}$ \\
\hline 1 & 0.00 & 8.56 & 0.43 & 0.29 & 0.54 & -2.53 & -55.98 & 0.00 & 0.00 & 0.84 \\
\hline 2 & 0.00 & 5.92 & 0.76 & 1.58 & 0.92 & 0.00 & -53.15 & 0.00 & 0.00 & 1.57 \\
\hline 3 & 0.00 & 10.11 & 1.75 & -2.64 & -0.62 & 0.89 & -56.71 & 0.00 & 0.00 & 0.00 \\
\hline 4 & 0.14 & 7.62 & 0.55 & 0.45 & 0.76 & -2.50 & -52.44 & 0.21 & 0.30 & 1.21 \\
\hline 5 & 0.10 & 7.75 & 0.51 & 0.37 & 0.69 & -2.62 & -54.17 & 0.00 & 0.33 & 1.16 \\
\hline 6 & 0.04 & 8.36 & 0.47 & 0.37 & 0.60 & -2.45 & -54.41 & 0.17 & 0.00 & 0.90 \\
\hline 7 & 0.00 & 8.43 & 0.44 & 0.23 & 0.56 & -2.66 & -55.79 & 0.00 & 0.00 & 0.97 \\
\hline 8 & 0.31 & 9.85 & 3.08 & -4.61 & -0.97 & 4.17 & -47.19 & 0.95 & 0.30 & 0.00 \\
\hline 9 & 0.00 & 5.76 & 0.89 & 1.86 & 1.11 & 0.46 & 0.00 & 0.00 & 0.00 & 1.56 \\
\hline 10 & 0.00 & 5.85 & 0.89 & 1.85 & 1.10 & 0.44 & 0.00 & 0.00 & 0.00 & 1.54 \\
\hline 11 & 0.03 & 6.03 & 0.94 & 1.84 & 1.21 & 0.59 & 0.00 & 0.32 & -0.12 & 1.55 \\
\hline 12 & 0.04 & 6.08 & 0.94 & 1.83 & 1.21 & 0.55 & 0.00 & 0.32 & -0.11 & 1.55 \\
\hline 13 & 0.27 & 8.92 & 4.16 & -5.04 & -1.30 & 9.01 & 0.00 & 1.29 & -0.08 & 0.00 \\
\hline 14 & 0.27 & 8.97 & 4.16 & -5.04 & -1.30 & 8.98 & 0.00 & 1.29 & -0.06 & 0.00 \\
\hline 15 & 0.41 & 8.69 & 0.79 & 0.70 & 1.21 & -2.65 & -49.43 & 0.00 & 1.32 & 1.66 \\
\hline 16 & -0.47 & 8.69 & 0.62 & 1.48 & 0.59 & 0.88 & 0.00 & 0.00 & -1.47 & 0.80 \\
\hline 17 & -0.45 & 8.65 & 0.63 & 1.48 & 0.61 & 0.82 & 0.00 & 0.00 & -1.39 & 0.82 \\
\hline
\end{tabular}

Source. Authors' calculations 
Table 4. Welfare results of a 50 percent tariff cut with different closure rules

\begin{tabular}{ccccccc}
\multicolumn{7}{c}{ (percentage change from base) } \\
\hline \multirow{2}{*}{ closures } & $\begin{array}{c}\text { Rural } \\
\text { Poor }\end{array}$ & $\begin{array}{c}\text { Rural NP } \\
\text { uned }\end{array}$ & $\begin{array}{c}\text { Eural NP } \\
\text { Educ }\end{array}$ & $\begin{array}{c}\text { Urban } \\
\text { Poor }\end{array}$ & $\begin{array}{c}\text { Urban NP } \\
\text { Uned }\end{array}$ & $\begin{array}{c}\text { Urban NP } \\
\text { Educ }\end{array}$ \\
\hline 1 & 0.43 & 0.56 & 0.41 & 0.36 & 0.28 & 0.40 \\
2 & -0.40 & -0.25 & 0.17 & 0.70 & 0.46 & 0.03 \\
3 & 0.38 & 0.50 & 0.55 & 0.55 & 0.34 & 0.62 \\
4 & 0.26 & 0.33 & 0.75 & 0.99 & 0.81 & 0.70 \\
5 & 0.26 & 0.33 & 0.71 & 0.91 & 0.73 & 0.68 \\
6 & 0.42 & 0.55 & 0.47 & 0.48 & 0.38 & 0.44 \\
7 & 0.38 & 0.49 & 0.47 & 0.50 & 0.42 & 0.47 \\
8 & 0.18 & 0.23 & 1.13 & 1.61 & 1.18 & 1.17 \\
9 & -0.65 & -0.58 & 0.17 & 0.39 & 0.21 & 0.27 \\
10 & -0.47 & -0.30 & 0.21 & 0.27 & 0.11 & -0.09 \\
11 & -0.57 & -0.48 & 0.16 & 0.39 & 0.24 & 0.24 \\
12 & -0.40 & -0.23 & 0.21 & 0.30 & 0.16 & -0.09 \\
13 & -0.56 & -0.50 & 0.74 & 1.26 & 0.79 & 0.91 \\
14 & -0.41 & -0.28 & 0.79 & 1.19 & 0.73 & 0.62 \\
15 & -0.09 & -0.16 & 1.47 & 2.23 & 1.72 & 1.36 \\
16 & -0.28 & -0.01 & -0.98 & -1.53 & -1.24 & -0.75 \\
17 & -0.09 & 0.27 & -0.88 & -1.56 & -1.28 & -1.10 \\
\hline
\end{tabular}

Source: author's calculations 
Table 5. The scenarios simulated

name of the scenario description

\begin{tabular}{ll}
\hline MARG DECR & $10 \%$ decrease in all margins \\
TARCUT & $50 \%$ cut in all import tariffs \\
EXP PR INCR & $10 \%$ increase in prices of export crops \\
IMP PR INCR & $10 \%$ increase in prices of imports of food and agric. products \\
IMP EXP PR INCR & $\begin{array}{l}10 \% \text { increase in prices of export crops and 10\% increase in prices of } \\
\text { imports of food and agric. products }\end{array}$ \\
MULT TRADE LIB & $\begin{array}{c}10 \% \text { increase in prices of export crops, } 10 \% \text { increase in prices of } \\
\text { imports of food and agric. products and } 50 \% \text { cut in all tariffs }\end{array}$ \\
\hline
\end{tabular}

Table 6. Aggregate results of simulation experiments under the preferred closure

\begin{tabular}{|c|c|c|c|c|c|c|c|c|c|}
\hline experiments & GPD & $\begin{array}{l}\text { agricultural } \\
\text { import }\end{array}$ & $\begin{array}{l}\text { total a } \\
\text { imports }\end{array}$ & $\begin{array}{l}\text { agricultural } \\
\text { export }\end{array}$ & $\begin{array}{c}\text { total } \\
\text { exports } \mathrm{i}\end{array}$ & $\begin{array}{l}\text { aggregate g } \\
\text { investment }\end{array}$ & $\begin{array}{l}\text { overnment } \\
\text { savings }\end{array}$ & $\begin{array}{l}\text { unskilled } \\
\text { labour }\end{array}$ & $\begin{array}{l}\text { rchange } \\
\text { rate }\end{array}$ \\
\hline$\overline{\mathrm{BASE}}$ & 7.80 & 247.86 & 2093.46 & 225.72 & 1078.05 & 1.00 & 92.49 & 2.46 & $\overline{1.00}$ \\
\hline MARG DECR & 3.71 & -1.58 & 6.88 & 31.38 & 6.30 & 0.66 & 16.2 & 12.78 & 3.96 \\
\hline TARCUT & 0.41 & 8.69 & 0.79 & 0.70 & 1.21 & -2.65 & -49.4 & 1.32 & 1.66 \\
\hline MARG \& TARCUT & 4.21 & 7.16 & 7.80 & 32.52 & 7.65 & -2.10 & -37.9 & 14.65 & 5.68 \\
\hline EXP PR INCR & 0.40 & 7.27 & 1.49 & 1.44 & -1.41 & 0.95 & -1.15 & 1.35 & -4.72 \\
\hline IMP PR INCR & 0.31 & -10.76 & -1.13 & -0.76 & -0.11 & 0.16 & 1.99 & 0.99 & -0.49 \\
\hline IMP EXP PR INCR & 0.71 & -4.00 & 0.29 & 0.76 & -1.50 & 1.11 & 0.89 & 2.36 & -5.18 \\
\hline MULT TRADE LIB & 1.09 & 1.49 & 1.03 & 1.56 & -0.32 & -1.50 & -46.7 & 3.65 & -3.63 \\
\hline
\end{tabular}

Source. Authors'calculations 
Table 7. Welfare results of simulation experiments under the preferred closure (percentage change from base)

\begin{tabular}{|c|c|c|c|c|c|c|}
\hline & $\begin{array}{l}\text { Rural } \\
\text { Poor }\end{array}$ & $\begin{array}{c}\text { Rural } \\
\text { NP } \\
\text { uned } \\
\end{array}$ & $\begin{array}{c}\text { Rural NP } \\
\text { Educ }\end{array}$ & $\begin{array}{c}\text { Urban } \\
\text { Poor }\end{array}$ & $\begin{array}{c}\text { Urban NP } \\
\text { Uned }\end{array}$ & $\begin{array}{c}\text { Urban NP } \\
\text { Educ }\end{array}$ \\
\hline MARG DECR & 5.07 & 3.69 & 7.43 & 9.35 & 7.86 & 7.03 \\
\hline TARCUT & -0.09 & -0.16 & 1.47 & 2.23 & 1.72 & 1.36 \\
\hline MARG \& TARCUT & 5.03 & 3.56 & 9.15 & 11.97 & 9.88 & 8.59 \\
\hline EXP PR INCR & 0.41 & 0.16 & 1.31 & 2.32 & 1.52 & 0.93 \\
\hline IMP PR INCR & 0.06 & $-0.1 \mathrm{C}$ & 0.10 & 0.16 & 0.12 & -0.06 \\
\hline IMP EXP PR INCR & 0.46 & 0.06 & 1.40 & 2.48 & 1.63 & 0.86 \\
\hline MULT TRADE LIB & 0.35 & -0.12 & 2.82 & 4.65 & 3.30 & 2.17 \\
\hline
\end{tabular}

Source. Authors'calculations 


\section{Table 8. simulations with increasing degrees of tariff cut}

(figures are percent deviations from base levels)

\begin{tabular}{|c|c|c|c|c|c|c|c|c|c|}
\hline experiments & GPD & $\begin{array}{l}\text { agricultural } \\
\text { imports }\end{array}$ & $\begin{array}{l}\text { total } \\
\text { imports }\end{array}$ & $\begin{array}{l}\text { agricultural } \\
\text { export }\end{array}$ & $\begin{array}{c}\text { total } \\
\text { exports }\end{array}$ & $\begin{array}{l}\text { aggregate } \\
\text { investment }\end{array}$ & $\begin{array}{c}\text { government } \\
\text { savings }\end{array}$ & $\begin{array}{l}\text { unskilled } \\
\text { labour }\end{array}$ & $\begin{array}{c}\text { exchange } \\
\text { rate }\end{array}$ \\
\hline ASE LEVELS & 7.80 & 247.86 & 2093.46 & 225.72 & 1078.05 & 1.00 & 92.49 & 2.46 & 1.00 \\
\hline 0 percent tariff cut & 0.41 & 5.81 & 0.79 & 0.70 & 1.21 & -2.65 & 46.8 & 1.32 & 1.66 \\
\hline percent tariff cut & 0.49 & 7.07 & 0.96 & 0.85 & 1.46 & -3.21 & 37.2 & 1.59 & 2.00 \\
\hline 0 percent tariff cut & 0.57 & 8.36 & 1.12 & 0.99 & 1.71 & -3.78 & 27.5 & 1.87 & 2.35 \\
\hline 80 percent tariff cut & 0.65 & 9.70 & 1.29 & 1.14 & 1.97 & -4.36 & 17.7 & 2.14 & 2.70 \\
\hline 90 percent tariff cut & 0.74 & 11.08 & 1.47 & 1.29 & 2.23 & -4.95 & 7.7 & 2.42 & 3.05 \\
\hline elimination of tariffs & 0.82 & 12.49 & 1.65 & 1.44 & 2.50 & -5.55 & -2.5 & 2.70 & 3.41 \\
\hline
\end{tabular}

Souce. Authors'calculations 

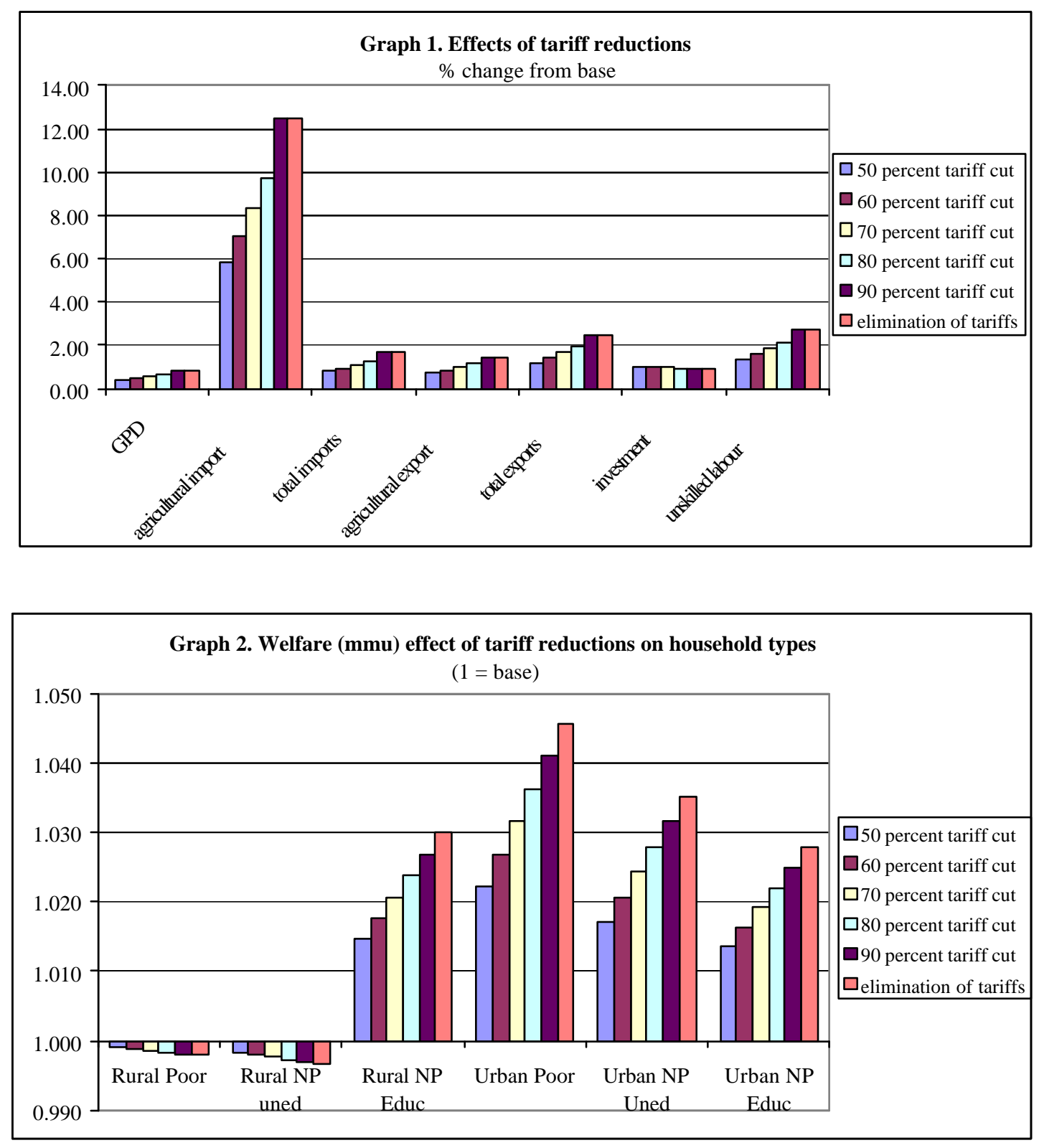

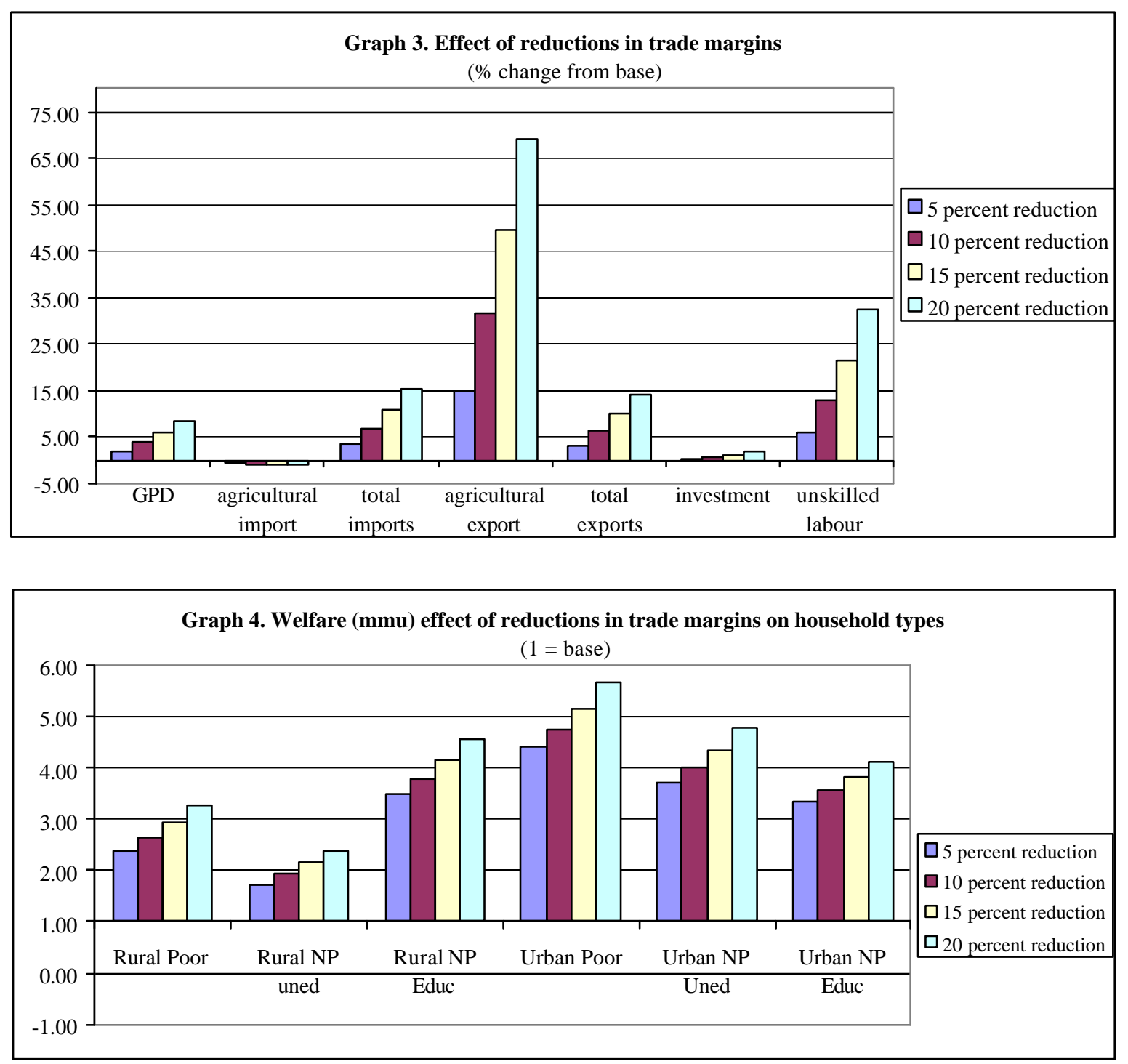